DOI: https://doi.org/10.24127/ajpm.v10i4.4179

\title{
ANALISIS KESULITAN PEMAHAMAN KONSEP DAN KEMANDIRIAN BELAJAR PADA PROSES PEMBELAJARAN MATEMATIKA SELAMA PANDEMI COVID-19
}

\author{
Mentari Izzati*1, Rizqi Amaliyakh Sholikhakh ${ }^{2}$, Suwandono ${ }^{3}$ \\ ${ }^{1 *, 2,3}$ Universitas Pancasakti Tegal, Tegal, Indonesia \\ ${ }^{*}$ Corresponding author. Tegal, 52193, Tegal, Indonesia. \\ E-mail: $\quad$ mentariizzati0406@gmail.com ${ }^{1 *}$ \\ rizqias@upstegal.ac.id ${ }^{2}$ \\ suwandono1@gmail.com $^{3)}$
}

Received 30 August 2021; Received in revised form 17 November 2021; Accepted 27 December 2021

\begin{abstract}
Abstrak
Penelitian ini bertujuan untuk mendeskripsikan letak kesulitan pemahaman konsep peserta didik pada materi statistika dan keterkaitan antara pemahaman konsep dengan kemandirian belajar peserta didik kelas VIII SMP Negeri 1 Dukuhturi. Penelitian ini merupakan penelitian deskriptif dengan pendekatan kualitatif. Subjek dalam penelitian ini adalah 6 peserta didik kelas VIII E SMP Negeri 1 Dukuhturi, yang dipilih dari masing-masing pemahaman konsep dengan menggunakan teknik purposive sampling. Penentuan subjek penelitian didasarkan pada hasil tes pemahaman konsep matematika peserta didik. Teknik pengumpulan data yang digunakan adalah tes pemahaman konsep matematika, wawancara, angket kemandirian belajar, dan dokumentasi. Hasil peneliti menunjukkan bahwa yang mempunyai tingkat pemahaman konsep tinggi belum tentu memiliki kemandirian belajar yang tinggi juga. Hasil analisis penelitian menunjukkan bahwa: 1) Letak kesulitan pemahaman konsep matematika pada materi statistika, ketidakmampuan dalam menentukan kuartil dengan benar, dalam mengaitkan konsep eksternal matematika yaitu materi aljabar dan perbandingan, serta dalam memahami soal cerita. 2) Keterkaitan antara pemahaman konsep dengan kemandirian belajar pada subjek T1 dan S2 mempunyai keterkaitan. Sementara pada subjek T2, S1, R1 dan R2 tidak ada keterkaitan antara pemahaman konsep dengan kemandirian belajar matematika.
\end{abstract}

Kata kunci: Analisis; kemandirian belajar; pemahaman konsep.

\begin{abstract}
This study aims to describe the students' difficulty of concepts understanding in statistical material and the relationship between conceptual understanding and self-rugulated learning of students in class VIII of SMP Negeri 1 Dukuhturi. This research is a descriptive research with a qualitative approach. The subjects in this study were 6 students of class VIII E of SMP Negeri 1 Dukuhturi, who were selected from each concept understanding using purposive sampling technique. The determination of the research subjects is based on the results of students' understanding of mathematical concepts. The data collection techniques used were tests of understanding mathematical concepts, interviews, self-regulated learning questionnaires, and documentation. The results of the study indicate that those who have a high level of conceptual understanding do not necessarily have high self-regulated learning as well. The results of the research analysis show that: 1) The difficulty of understanding mathematical concepts in statistical material, the inability to determine quartiles correctly, in relating external mathematical concepts, namely algebra and comparison materials, as well as in understanding story problems. 2) There is a correlation between understanding the concept and self-regulated learning on the subject of T1 and S2. Meanwhile, in the subjects of T2, S1, R1 and R2, there is no correlation between concept understanding and self-regulated learning of mathematics.
\end{abstract}

Keywords: Analysis; conceptual understanding; self-regulated learning.

This is an open access article under the Creative Commons Attribution 4.0 International License 
DOI: https://doi.org/10.24127/ajpm.v10i4.4179

\section{PENDAHULUAN}

Pemahaman konsep adalah suatu kemampuan yang mana wajib dipunyai oleh peserta didik pada saat belajar matematika. Pemahaman konsep menjadi bagian kognitif yang dinilai penting sekali pada belajar matematika, dikarenakan matematika tidak hanya sekadar menghafal tetapi harus paham konsep untuk diterapkan pada kegiatan sehari-harinya. Banyak sekali siswa yang mana merasa susah dalam hal pemahaman konsep, padahal kemampuan yang wajib dipunyai dan hal dasar pada pembelajaran matematika yang harus dipunyai yaitu memahami konsep matematik (Febriantika, 2020).

Pada masa sekarang ini, dunia digemparkan oleh suatu penyakit bernama Covid-19 (CoronaVirus Diseases-19) yang berasal dari Wuhan, China. Covid-19 adalah jenis virus yang penyebarannya sangat cepat. Dalam suatu bencana ini, seluruh negara juga terkena imbasnya, baik negara yang sudah maju maupun negara yang masih berkembang. Salah satunya negara yang berkembang seperti Indonesia juga terkena imbasnya dan mempengaruhi banyak kelumpuhan, seperti lumpuhnya di bidang kesehatan, ekonomi, pariwisata dan pendidikan. Dengan lumpuhnya di bidang pendidikan, yang mana semua hal yang menyangkut dengan pendidikan dilakukan secara daring (online). Secara garis besar, semua peserta didik mendapatkan pembelajaran secara daring.

Pendidikan di Indonesia, mengedepankan karakter dalam abad ke-21 untuk penghadapan tantangan yang dapat dijelaskan bahwa dalam abad ke-21 meliputi pembelajaran dalam pengintegrasian peningkatan literasi, kemampuan teknologi yang harus dikuasai, sikap serta keterampilannya, serta kemampuan dalam pengetahuan secara umum. (Kemendikbud, 2017). Untuk menghadapi tantangan tersebut, pemerintah memberi ruang gerak dengan adanya kurikulum 2013. Dalam Kurikulum 2013 murid diberikan tuntutan dalam mencari tahu serta tidak pasif pada setiap proses belajar. Maka, dalam suatu pembelajaran daring tetap harus diterapkan aspek yang lain seperti afektif dan psikomotor. Kemandirian belajar adalah aspek afektif yang diterapkan dalam belajar secara dalam jaringan atau online pada waktu wabah covid-19 terjadi, dikarenakan seseorang yang mana memiliki kemandirian belajar mampu mengevaluasi diri sendiri.

Kemampuan peserta didik untuk mewujudkan keinginan dan kehendaknya secara nyata tanpa bergantung pada orang lain, dimana peserta didik dapat melakukan belajar sendiri, menentukan belajar yang efektif dan sanggup melakukan aktivitas belajar yang mandiri disebut dengan kemandirian belajar (Arifin \& Herman, 2018).

Penelitian terdahulu yang dilakukan (Kartika, 2018), (Maghfiroh, 2020) dan (Mayasari \& Habeahan, 2021) menjelaskan bahwasannya peserta didik dalam kemampuan memahami konsep tergolong masih kurang. Dalam penelitian yang dilakukan (Erfani dkk., 2020) dan (Vindianti, 2020), faktor penyebab kesalahan peserta didik yaitu tidak dapat mengafal atau mengingat suatu rumus dalam penyelesaian permasalahan, tidak pahamnya menyelesaiakan rencana dengan langkah yang baik dan langkah mana yang akan diambil, kurang mampunya dalam pengaitan kalimat matematika dalam soal, kurangnya pemahaman apa yang diminta dan maksud dari soalnya, 
sehingga tidak menerapkan apa yang diketahui serta ditanyakan pada soalnya, serta peserta didik belum memeriksa kembali langkah pada pelaksanaaan rencana. Sedangkan menurut penelitian (Anggraeni, 2016) dijelaskan bahwasanya dalam memahami konsep dalam matematika masih sangat minim, namun kemandirian peserta didik dikategorikan baik, sehingga tidak terlalu terkait antara memahami konsep matematik peserta didik dengan kemandirian dalam proses belajar. Berdasarkan hasil penelitian terdahulu, peneliti akan angkat pembaharuan sehingga dapat menjadi gambaran mengenai kesulitan memahami konsep serta kemandirian dalam pembelajaran matematik dalam masa wabah penyakit covid-19.

Dalam kegiatan wawancara dengan salah satu guru di SMP Negeri 1 Dukuhturi, menghasilkan bahwa para siswa merasa sulit pada pemahaman konsep matematika. Selain itu, pada masa pandemi, peserta didik dituntut untuk belajar mandiri. Maka, pada penelitian kali ini bertujuan dalam mengetahui letak kesulitan memahami konsep serta keterkaitan antara pemahaman konsep dan kemandirian belajar peserta didik di SMP Negeri 1 Dukuhturi.

\section{METODE PENELITIAN}

Penelitian ini merupakan jenis deskriptif dengan pendekatan kualitatif. Penelitian ini memiliki maksud dalam pendeskripsian kesulitan pemahaman konsep dan keterkaitan memahami konsep dengan kemandirian belajar matematika peserta didik. Materi dalam meneliti hal ini merupakan statistika. Subjek pada penelitian ini adalah siswa kelas VIII SMP N 1 Dukuhturi, dengan jumlah 29 siswa yang mana menjadi subjek dalam penelitian terdiri atas 6 dengan menggunakan teknik purposive sampling, yaitu 2 orang peserta didik yang mana mempunyai memahami konsep tinggi, dua orang siswa mempunyai pemahaman konsep sedang, dan 2 orang peserta didik yang mempunyai pemahaman konsep rendah.

Instrumen yang digunakan yaitu tes uraian pemahaman konsep, pedoman wawancara serta berupa angket kemandirian belajar. Intrumen tes yang digunakan untuk penelitian, telah dilakukan uji coba, sementara pedoman wawancara dan angket telah dilakukan validasi oleh validasi ahli. Tes pemahaman konsep mengacu pada indikator menurut Klipatrick, Swafford, \& Findell dalam (Muhandaz dkk., 2018), adalah: 1) pernyataan ulang konsep yang telah dipelajari, 2) mengelompokkan objek-objek berdasarkan terpenuhi maupun tidaknya persyaratan dalam pembentukkan konsep tersebut, 3) penerapan konsep secara algoritma, 4) penyajian konsep pada berbagai macam bentuk representasi matematika, 5) pengaitan berbagai konsep (internal dan eksternal matematika). Instrumen wawancara, dipergunakan dalam penguatan data hasil ujian memahami konsep matematika peserta didik. Sedangkan angket, dipergunakan dalam pengukuran tingkat kemandirian pembelajaran matematika peserta didik. Angket kemandirian dalam belajar mengacu pada indikator menurut (Lestari \& Yudhanegara, 2017), adalah: 1) inisiatif dalam belajar, 2) mempunyai kemampuan dalam penentuan nasib diri, 3) mendiagnosis kebutuhan belajar, 4) kreatif serta memiliki sikap inisiatif pada pemanfaatan sumber belajar serta pemilihan strategi dalam belajar, 5) pemonitoran, pengaturan, serta pengontrolan dalam belajar, 6) mampu menahan diri, 7) membuat keputusan- 
DOI: $\underline{\text { https://doi.org/10.24127/ajpm.v10i4.4179 }}$

keputusan sendiri, 8) kemampuan dalam mengatasi masalah.

Pengumpulan data dilaksanakan dengan cara 1) pemberian soal-soal ujian uraian materi statistika dengan indikator pemahaman konsep matematika kepada peserta didik yang berjumlah 5 soal. (2) menganalisis jawaban peserta didik, lalu diambil 6 subjek yaitu kelompok yang rendah, sedang, serta tinggi kemudian dilakukan wawancara untuk memperkuat data tes. (3) melakukan penyebaran angket terhadap peserta didik yang bertujuan dalam mengetahui tingkat kemandirian belajar matematika.

Analisis data yang dilaksanakan yaitu melakukan reduksi data dengan cara merangkum atau penyederhanaan data tes, wawancara, dokumentasi, angket. Selanjutnya menyajikan sebuah data bersama cara penyusunan kumpulan berita dari hasil reduksi data supaya semakin mudah dipahami.
Kemudian menarik hasil kesimpulan pada penelitian kualitatif.

\section{HASIL DAN PEMBAHASAN}

Dalam meneliti, membahas mengenai letak kesulitan pemahaman konsep dan keterkaitan pemahaman konsep dengan kemandirian belajar peserta didik. Dalam penelitian ini, peneliti menganalisis hasil tes pemahaman konsep materi statistika. Keenam subjek akan dianalisis letak kesulitan pemahaman konsep pada materi statistika. Berikut ini penjelasannya:

Dari soal nomor 2 yaitu "Nilai rata-rata ulangan matematika dari 20 siswa yaitu 60. Bila dijumlahkan dengan sejumlah siswa yang mempunyai rata-rata 70 , maka nilai rata-ratanya menjadi 62. Hitunglah banyak siswa yang ditambahkan!" diperoleh jawaban tes peserta didik pada Gambar 1-3.

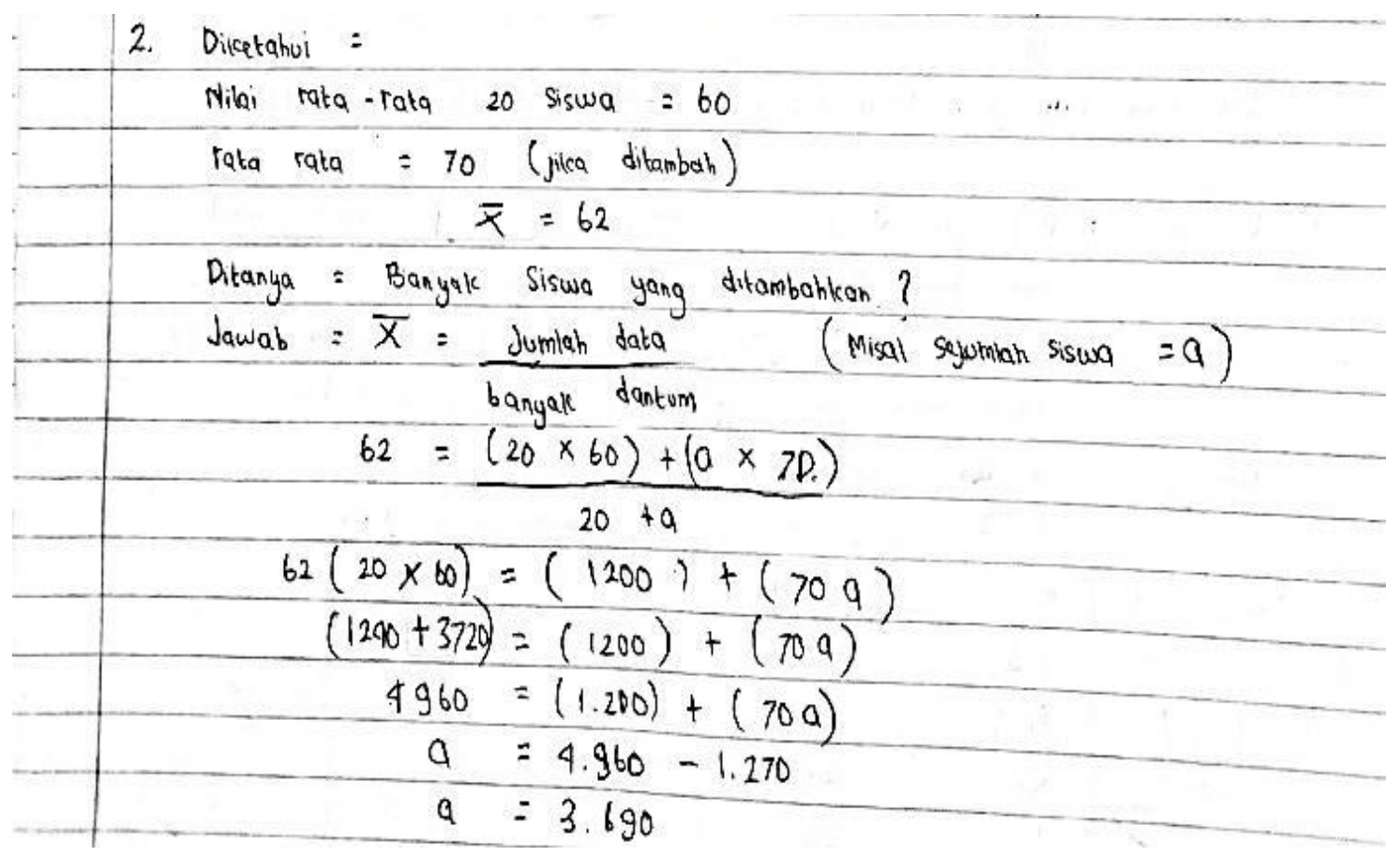

Gambar 1. Jawaban soal nomor 2 subjek T1 
DOI: https://doi.org/10.24127/ajpm.v10i4.4179

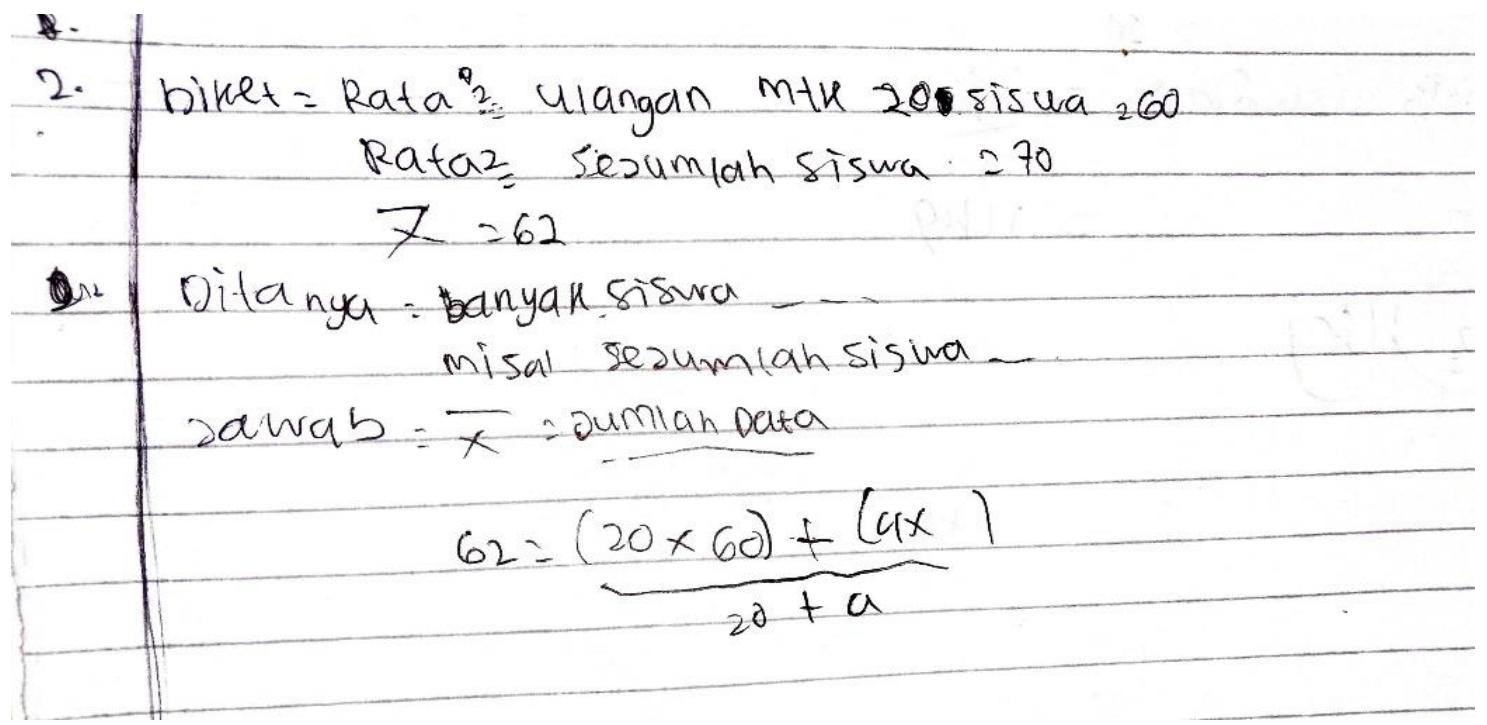

Gambar 2. Jawaban soal nomor 2 subjek S1

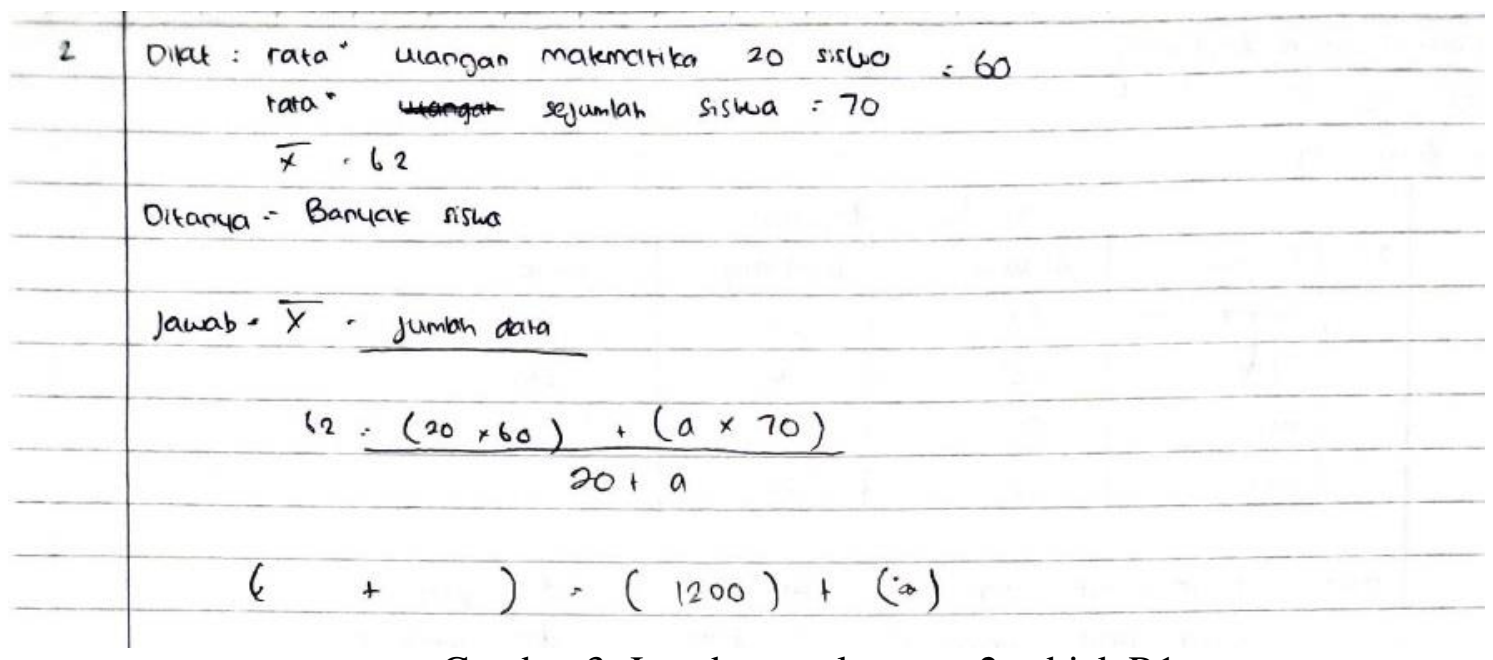

Gambar 3. Jawaban soal nomor 2 subjek R1

Berdasarkan jawaban subjek T1

(Gambar 1), didapatkan informasi bahwa peserta didik masih banyak kesalahan dalam proses aljabar, sehingga tidak mendapatkan jawaban yang benar. Berdasarkan hasil wawancara, peserta didik juga merasa kesulitan ketika mengerjakan soal nomor 2 pada bagian perhitungan aljabar. Berdasarkan jawaban subjek S1 (Gambar 2) dan R2 (Gambar 3) juga tidak dapat melanjutkan proses pengerjaannya karena peserta didik tidak tahu cara menghitungnya. Berdasarkan hasil wawancara, didapatkan juga informasi bahwa peserta didik kurang menguasai pada materi aljabar sehingga peserta didik merasa kesulitan ketika mengaitkan aljabar pada materi statistika. Selain itu, subjek S1, R2, dan T1 merasa kebingungan dengan soal nomor 2 karena soal tersebut disajikan dalam bentuk cerita.

Dari soal nomor 4 yaitu "Diketahui nilai ulangan Matematika 10 siswa di SMP Negeri 1 Dukuhturi

\begin{tabular}{cccccc} 
Nilai & 60 & 70 & 80 & 90 & 100 \\
Frekuensi & 1 & 3 & 3 & 1 & 2 \\
\hline
\end{tabular}


DOI: $\underline{\text { https://doi.org/10.24127/ajpm.v10i4.4179 }}$

Hitunglah jangkauan, kuartil, dan jangkauan interkuartil !" diperoleh

jawaban peserta didik pada Gambar 4-6.

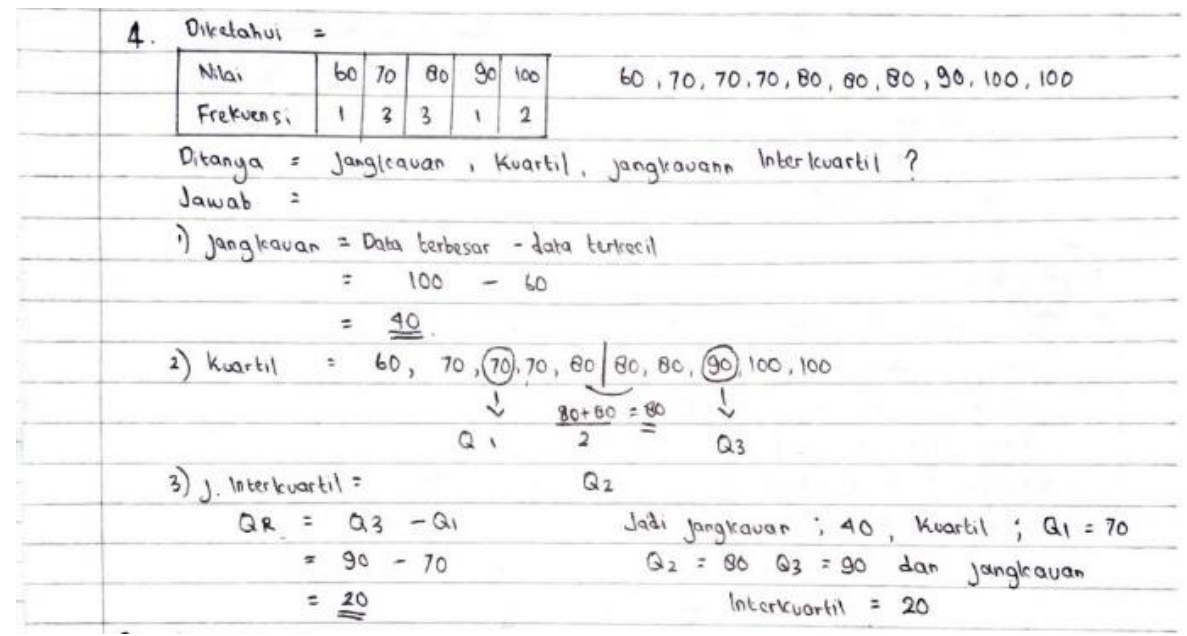

Gambar 4. Jawaban soal nomor 4 subjek T2

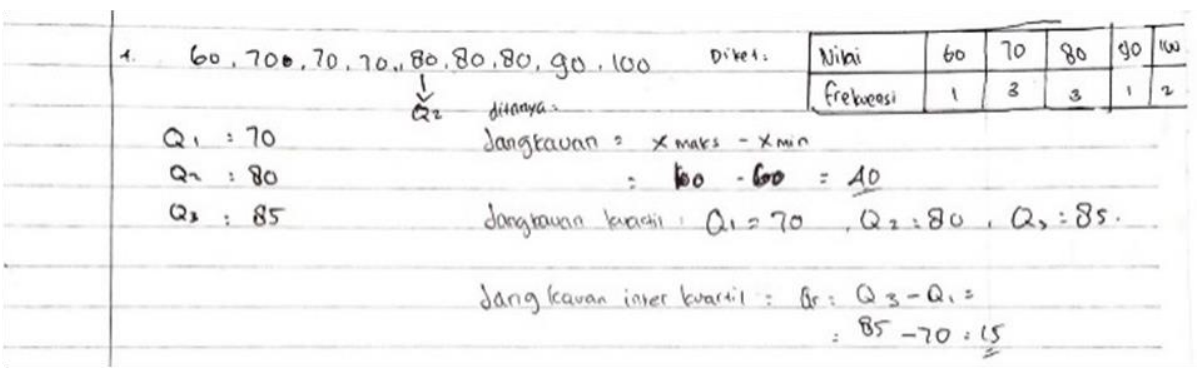

Gambar 5. Jawaban soal nomor 4 subjek S2

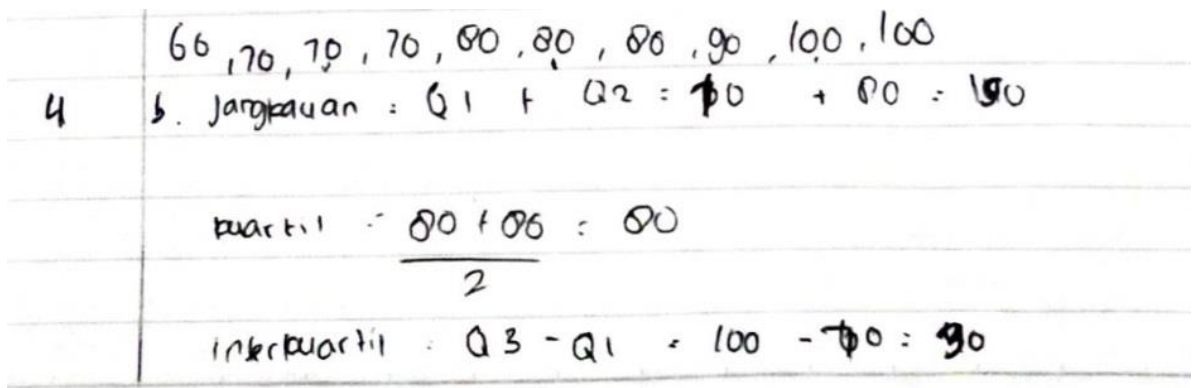

Gambar 6. Jawaban soal nomor 4 subjek R2

Berdasarkan jawaban peserta didik, diperoleh informasi bahwa masih terdapat kesalahan dalam menentukan kuartil. Pada subjek T2 (Gambar 4) dan R2 (Gambar 6), kesalahannya adalah ketika menentukan kuartil atas. Sedangkan pada subjek S2 (Gambar 5), hanya mampu menjawab kuartil tengah saja, dan tidak mampu menjawab kuartil bawah dan kuartil atas. Hal ini dikarenakan peserta didik masih kurang mampu dalam membagi data dan tidak mempunyai strategi lain selain membagi-bagi data dalam menentukan kuartil sehingga mengakibatkan kekeliruan dalam menentukan kuartil.

.Peneliti mengetahui hal tersebut ketika dilakukannya wawancara dengan para siswa mengenai respon tes para siswa yang ada. 
DOI: $\underline{\text { https://doi.org/10.24127/ajpm.v10i4.4179 }}$

Selanjutnya dari soal nomor 5 yaitu "Perbandingan jumlah siswa perempuan serta laki-laki pada satu kelas yaitu 3 : 2 . Jika total siswa perempuan terdapat 12 orang. Tentukan rata-rata berat badan siswa laki-laki bila jumlah beratnya siswa laki-laki 396 kg!" diperoleh jawaban peserta didik Pada Gambar 7-9

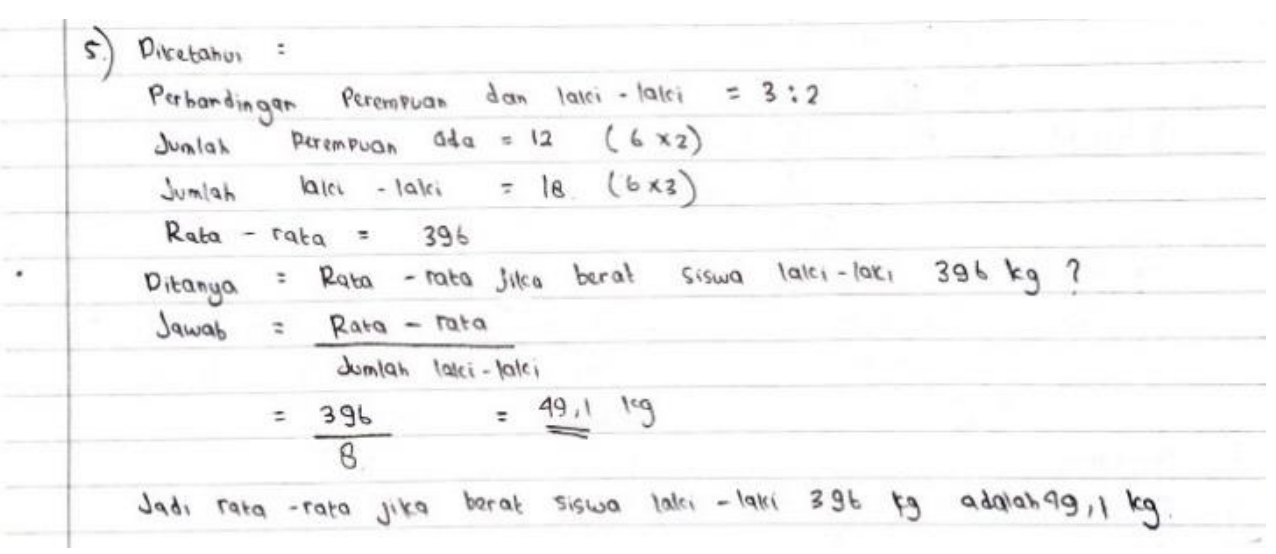

Gambar 7. Jawaban soal nomor 5 subjek T2

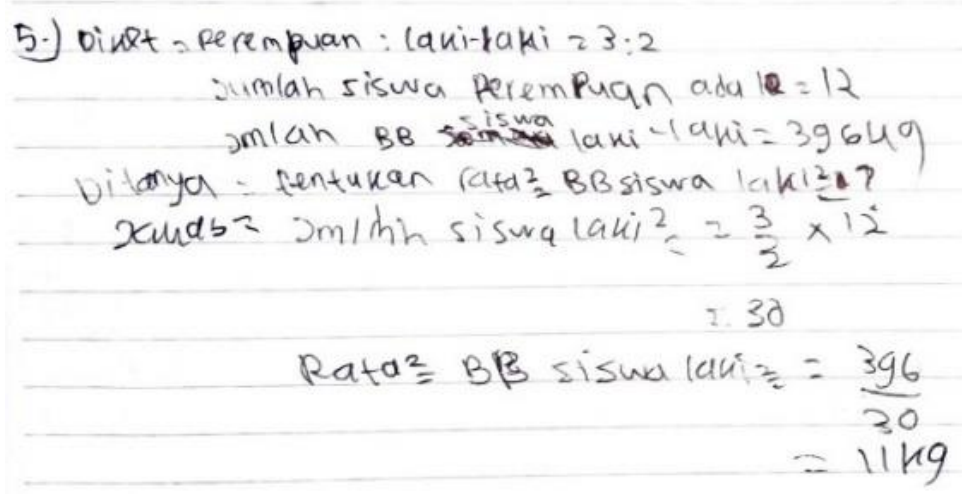

\section{Dad) Rataz $11 \% \mathrm{cg}$}

Gambar 8. Jawaban soal nomor 5 subjek S1

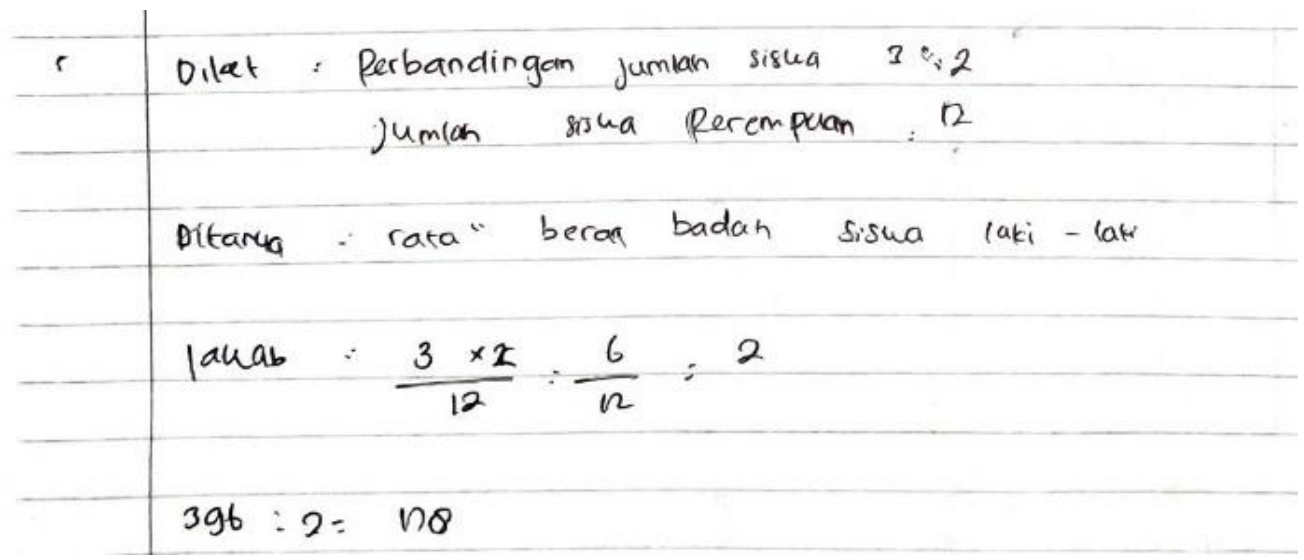

Gambar 9. Jawaban soal nomor 5 subjek R2 
DOI: https://doi.org/10.24127/ajpm.v10i4.4179

Berdasarkan jawaban subjek T2 (Gambar 7), mampu dalam mengerjakan soal nomor 5, tetapi peserta didik melewati proses pada saat mencari jumlah siswa laki-laki, yaitu pada saat mengaitkan materi perbandingan. Dari hasil wawancara, subjek T2 tidak mampu dalam mengaitkan materi perbandingan pada saat mengerjakan soal tersebut. Sehingga nilai tersebut diperoleh dengan melihat jawaban teman, serta subjek T2 juga merasa kebingungan dalam menghadapi soal cerita materi statistika. Begitu juga dengan subjek S1 (Gambar 8) dan R2 (Gambar 9) yang masih banyak kesalahan dalam mengaitkan perbandingan pada materi statistika. Subjek S1 dan R2 juga merasa kebingungan ketika diberikan soal cerita pada materi statistika.

Berdasarkan penelitian sebelumnya oleh (Kartika, 2018), bahwa kesulitan peserta didik dalam mempelajari materi aljabar adalah merasa susah dalam hal substitusi persamaan yang telah diketahui, susah dalam materi aljabar dalam pengetahuan yang mendasar, merasa susah dalam menerapkan suatu bentuk soal cerita dalam konsep aljabar. Pada penelitian ini, kesulitan pemahaman konsep matematika pada materi statistika adalah ketidakmampuan peserta didik dalam menentukan kuartil, ketidakmampuan dalam mengaitkan konsep eksternal matematika yaitu materi aljabar dan perbandingan, serta ketidakmampuan dalam mengerjakan materi statistika yang berkaitan dengan soal cerita. Maka, ada kesamaan hasil penelitian ini dengan penelitian sebelumnya yaitu, peserta didik kesulitan dalam penerapan konsep pada soal cerita meskipun materi yang diteliti oleh peneliti berbeda.
Ada juga temuan baru pada kesulitan pemahaman konsep materi statistika yaitu peserta didik tidak dapat menentukan kuartil dengan tepat dan tidak mampu mengaitkan konsep eksternal matematika. Peserta didik dalam memahami konsep pada penelitian sebelumnya dinilai tergolong rendah serta dinilai kurang dalam kemampuannya terkait dengan memahami konsep, hal ini disebabkan perserta didik kurang dalam hal penuangan ulang konsep yang didapat serta penyajiannya ke dalam bentuk matematik serta kurangnya kompetensi dalam menjelaskan hal tersebut. Seperti halnya dengan penelitian ini, kemampuan peserta didik dalam memahami konsep juga masih tergolong kurang dan rendah. Hal ini disebabkan peserta didik kurang memenuhi indikator pemahaman konsep matematika. Jika dalam memahami suatu konsep dalam belajar matematik dirasa tercukupi, peserta didik baru dapat dikatakan mempunyai kemampuan dalam pemahaman konsep tersebut (Cahani \& Effendi, 2019). Hasil dari persentase indikator memahami konsep matematik dalam penelitian ini, dilihat dalam Tabel. 1.

Adapun hasil analisis data angket kemandirian belajar dari keenam subjek dalam penelitian ini disajikan pada Tabel 2.

Berdasarkan Tabel 2, dapat di deskripsikan bahwa siswa atau peserta didik dalam kemandirian belajar berada pada kelompok rendah, sedang, serta tinggi. Subjek yang berkategori tinggi yaitu T1, subjek yang berkategori sedang yaitu T2, S2, R1, dan R2, dan yang berkategori rendah yaitu $\mathrm{S} 1$. Kemandirian belajar tertinggi diperoleh T1 dengan persentase $80 \%$, sedangkan terendah diperoleh S1 dengan persentase $49 \%$. 
DOI: https://doi.org/10.24127/ajpm.v10i4.4179

Tabel 1. Persentase indikator pemahaman konsep matematika

\begin{tabular}{clccc}
\hline No & Indikator Pemahaman Konsep Matematika & Hasil (\%) & Kriteria \\
\hline 1 & $\begin{array}{l}\text { Menyatakan ulang konsep yang sudah } \\
\text { dipelajari }\end{array}$ & 68,33 & Cukup \\
2 & $\begin{array}{l}\text { Mengklasifikasikan objek-objek berdasarkan } \\
\text { dipenuhi atau tidaknya persyaratan untuk }\end{array}$ & 50 & Rendah \\
$\begin{array}{l}\text { membentuk konsep tersebut } \\
3\end{array}$ & 28,33 & Sangat Rendah \\
Menerapkan konsep secara logaritma & $\begin{array}{l}\text { Menyajikan konsep dalam berbagai macam } \\
\text { bentuk representasi matematika } \\
\text { Mengaitkan berbagai konsep (internal dan } \\
\text { eksternal matematika) }\end{array}$ & 33,67 & Rendah \\
\hline
\end{tabular}

Tabel 2. Persentase kemandirian belajar setiap subjek

\begin{tabular}{ccc}
\hline Subjek & Hasil $(\boldsymbol{\%})$ & Kriteria \\
\hline T1 & 80 & Tinggi \\
T2 & 77 & Sedang \\
S1 & 49 & Rendah \\
S2 & 71 & Sedang \\
R1 & 57 & Sedang \\
R1 & 78 & Sedang \\
\hline
\end{tabular}

Pada subjek T1, memiliki tingkat pemahaman konsep tinggi dan kemandirian yang tinggi juga, sehingga ada keterkaitan antara pemahaman konsep dengan kemandirian belajar. Begitu pula dengan subjek S2 yang mempunyai pemahaman konsep sedang, dan tingkat kemandirian belajar sedang juga. Kemampuan dalam memahami matematika serta dengan kemandirian belajar antara keduannya memiliki kaitan yang baik serta relevan (Mulianty dkk., 2018). Sama halnya pada penelitian Pada penelitian sebelumnya, menurut (Sari, 2020) yang berjudul "Analisis Kemampuan Pemahaman Matematis dan Kemandirian Belajar Mahasiswa pada Mata Kuliah Teori Bilangan di Tahun Akademik 2019/2020" dengan pengambilan subjek berdasarkan teknik purposive sampling berjumlah 6 mahasiswa dimana mempunyai kemampuan bermacam-macam serta bisa berkomunikasi dengan maksimal, subjek tersebut pada penelitian sebelumnya diberi inisial S1, S2, S3, S4, S5, dan S6. Terdapat 3 mahasiswa tingkat pemahaman matematis tinggi yaitu S1, S2, dan S3, serta terdapat 3 mahasiswa dengan pemahaman konsep sedang yaitu S4, S5, dan S6. Pada subjek S1, S2, dan S3, memiliki kemandirian belajar yang baik, maka terdapat keterkaitan antara pemahaman matematis dengan kemandirian belajar. Selain itu, pada subjek S4 dan S6, memiliki kemandirian belajar yang cukup, maka adapula keterkaitan antara pemahaman matematis dengan kemandirian belajar. Sedangkan pada subjek S5 dengan pemahaman konsep sedang, memiliki kemandirian belajar baik, maka seperti halnya dijelaskan bahwasannya tidak ada hubungannya antara kemandirian dengan kemampuan matematik (Hidayat \& Sumarmo, 2013).

Pada subjek R1 dan R2, mempunyai pemahaman konsep matematika rendah, akan tetapi tingkat kemandirian belajarnya sedang. Hal ini sejalan dengan penelitian terdahulu yaitu menurut (Anggraeni, 2016), yang mana memiliki judul "Analisis Kemampuan Pemahaman Konsep Matematis serta Kemandirian Belajar Siswa" dengan pengambilan subjek 
berdasarkan teknik simple random sampling berjumlah 6. Pada penelitian tersebut, pemahaman konsep yang dimiliki peserta didik sangat rendah sedangkan tingkat kemandirian belajar dikategorikan baik. Maka dari itu, tidak ada keterkaitan antara pemahaman konsep dengan kemandirian belajar matematika. Sama halnya seperti menurut (Sari, 2020), bahwa pada subjek S4 memiliki tingkat pemahaman matematis sedang dan kemandirian belajar baik. Hal tersebut karena peserta didik kurang mampu memenuhi indikator pemahaman matematis peserta didik.

Sedangkan pada subjek T2 mempunyai tingkat pemahaman konsep tinggi, akan tetapi tingkat kemandirian belajarnya sedang. Sama seperti pada subjek S1 yang mempunyai pemahaman konsep matematika sedang, tetapi tingkat kemandirian belajarnya rendah.

Adapun hal yang berbeda dari penelitian sebelumny bahwa dalam penelitian yang terdahulu dijelaskan, untuk pehamanan matematis sedang tetapi tingkat kemandirian belajar baik, dan pemahaman konsep rendah tetapi tingkat kemandirian belajar baik sementara pada penelitian ini, terdapat pemahaman konsep sedang, tetapi tingkat kemandirian belajar rendah. Faktor yang mempengaruhi hal ini adalah pada saat subjek $\mathrm{T} 2$ dan S1 mengerjakan soal tes, melihat jawaban teman. Sehingga mengakibatkan tingkat pemahaman konsepnya lebih tinggi dari kemandirian belajarnya. Hal tersebut peneliti ketahui ketika dilakukannya wawancara dengan peserta didik.

Ada juga kelebihan dari penelitian ini adalah untuk memberikan sebuah gambaran mengenai pembelajaran matematika di masa pandemi covid-19, sehingga mengetahui letak kesulitan apa saja yang dialami peserta didik. Sedangkan kekurangan pada penilitian ini adalah peneliti hanya menganalisis kondisi kesulitan internal saja, tidak pada eksternal peserta didik.

\section{KESIMPULAN DAN SARAN}

Berdasarkan analisis tersebut diperoleh bahwa letak kesulitan pemahaman konsep matematika pada materi statistika adalah ketidakmampuan peserta didik dalam menentukan kuartil, ketidakmampuan dalam mengaitkan konsep eksternal matematika yaitu aljabar dan perbandingan, serta ketidakmampuan dalam memahami soal cerita. Keterkaitan antara pemahaman konsep dengan kemandirian belajar pada subjek T1 dan S2 mempunyai keterkaitan. Sementara pada subjek T2, S1, R1 dan R2 tidak ada keterkaitan antara pemahaman konsep dengan kemandirian belajar matematika.

Saran untuk yang akan meneliti, supaya melakukan penelitian mengenai kemandirian dalam belajar matematika dengan pemahaman konsep disertai pengembangan aspek-aspek yang lain. Serta jika meneliti tentang kondisi kesulitan, maka disarankan tidak hanya meneliti pada internal saja, tetapi pada eksternal juga.

\section{DAFTAR PUSTAKA}

Anggraeni, F. (2016). Analisis Kemampuan Pemahaman Konsep Matematis dan Kemandirian Belajar Siswa. Academia Edu.

Arifin, F., \& Herman, T. (2018). Pengaruh Pembelajaran ELearning Model Web Centric Course Terhadap Pemahaman Konsep dan Kemandirian Belajar Matematika Siswa. Jurnal Pendidikan Matematika, 12(2), 112. 
Cahani, K., \& Effendi, K. N. S. (2019). Kemampuan Pemahaman Konsep Matematika Siswa SMP Kelas IX Pada Materi Bangun Datar Segiempat. Prosiding Sesiomadika, 2, 9.

Erfani, G. A., Rokhman, M. S., \& Sholikhakh, R. A. (2020). Analisis kesalahan siswa dalam menyelesaikan soal cerita matematika materi aritmetika sosial menurut Polya. AKSIOMA : Jurnal Matematika dan Pendidikan Matematika, 11(2), 306-314.

https://doi.org/10.26877/aks.v11i2 .6850

Febriantika, A. A. (2020). Kemampuan Pemahaman Konsep Matematis Ditinjau dari Kompetensi Keahlian. AlphaMath : Journal of Mathematics Education, 5(2), 1. https://doi.org/10.30595/alphamat h.v5i2.7329

Hidayat, W., \& Sumarmo, U. (2013). Kemampuan Komunikasi dan Berpikir Logis Matematik Serta Kemandirian Belajar. Delta-Pi: Jurnal Matematika dan Pendidikan Matematika, 2(1), 14.

Kartika, Y. (2018). Analisis Kemampuan Pemahaman Konsep Matematis Peserta Didik Kelas VII SMP Pada Materi Bentuk Aljabar. Jurnal Pendidikan Tambusai, 2 (9).

Kemendikbud. (2017). Panduan Implementasi Kecakapan Abad 21 Kurikulum 2013 Di Sekolah Menengah Atas.

Lestari, K. E., \& Yudhanegara, M. R. (2017). Penelitian Pendidikan Matematika. PT Refika Aditama.

Maghfiroh, L. (2020). Analisis Kesulitan Pemahaman Konsep Matematis Peserta Didik Dalam
Menyelesaikan Soal Pada Materi Penyajian Data Kelas VII SMP. Jurnal Penelitian, Pendidikan, dan Pembelajaran, 15(33), 38-44. Mayasari, D., \& Habeahan, N. L. S. (2021). Analisis Kemampuan Pemahaman Konsep Siswa Dalam Menyelesaikan Soal Cerita Matematika. AKSIOMA: Jurnal Program Studi Pendidikan Matematika, 10(1), 252. https://doi.org/10.24127/ajpm.v10 i1.3265

Muhandaz, R., Trisnawita, O., \& Risnawati, R. (2018). Pengaruh Model Pembelajaran Course Review Horay terhadap Kemampuan Pemahaman Konsep Matematis Berdasarkan Kemandirian Belajar Siswa SMK Pekanbaru. JURING (Journal for Research in Mathematics Learning), 1(2), 137.

Mulianty, H. R., Hanifah, A. N., \& Sugandi, A. I. (2018). Hubungan Antara Kemampuan Pemahaman Matematik Dengan Kemandirian Belajar Siswa SMP yang Menggunakan Pendekatan Kontekstual. JPMI (Jurnal Pembelajaran Matematika Inovatif), $\quad 1(6), \quad 1071$. https://doi.org/10.22460/jpmi.v1i6 .p1071-1078

Sari, I. W. (2020). Analisis Kemampuan Pemahaman Matematis dan Kemandirian Belajar Mahasiswa pada Mata Kuliah Teori Bilangan di Tahun Akademik 2019/2020. JURNAL WIDYALOKA IKIP WIDYA DARMA, 7(1), 11.

Vindianti, E. M. (2020). Analisis Kesalahan Peserta Didik Dalam Menyelesaikan Soal Uraian Matematika. UPS Repository, 72. 